\title{
Multipurpose uses of forage species, estimation of availability and distribution of grass species, and effect of location on the crude fibre and ash contents of common browse species in Nsukka, Nigeria. \\ C. C. Onyeonagu*, J. E. Asiegbu, A. R. Nweke, and C.S. Akagha Department of Crop Science University of Nigerian, Nsukka. "Corresponding Author E-mail: onyeonagu@yahoo.com

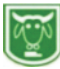

\begin{abstract}
A study of multipurpose browse and grass species from four rural communities of Nsukka Local Government Area of Enugu State was conducted between 2005 and 2006. Structured questionnaires were administered to farmers in the four communities. A total of 38 plant species belonging to 24 plant families were identified as multipurpose browse species. A greater number of the plant species are used for fuel wood (22 species), for fruits and leaves as vegetables (20 species) and for human and veterinary medicine (16 species). Twenty seven species of these browse plants from 2 communities were subjected to nutritional evaluation of their ash and crude fibre contents. The percentage crude fibre content of Icancina trichantha (73. 8\%) was highest compared with the other browse species. Browse species from Edemani community gave significantly $(P<0.05)$ higher crude fibre contents than those from Obukpa community. Elaeis guineensis had significantly $(P<0.05)$ the highest ash content $(23.5 \%)$. Plants from Edemani had higher ash content (11.4\%) than those from Obukpa community (8.1\%). Location and species interaction significantly $(P<0.05)$ affected the ash contents of the browse plants. A total of 6 plants were identified as multipurpose grass species. A greater number of the grass species are used for soil fertility enrichment (4 species), for lighting (2 species) and as roofing materials (2 species). The most frequently used grass species (with mean usage = 15\%) across all sampled communities include: Andropogon gayanus and Anthephora ampulaceae. All the grass species identified are moderately available in the area of study.
\end{abstract}

Keywords: Multipurpose uses, location, forage species.

\section{Introduction}

Browse in the form of trees and shrubs, form an integral part of ruminant production. The use of browse plants in ruminant animal nutrition has become an essential practice, especially in the dry season when herbaceous forages are scarce and of low quality (Bamikole et al., 2004; Onyeonagu and Asiegbu, 2006). Browse plants are available all the year round (all season), contributing their succulent leaves and twigs to small ruminant feeding and production (Onyeonagu and Asiegbu, 2006). In
Addition to their being used in feeding small ruminant in Nigeria, there are other multipurpose uses of browse which include human and veterinary medicine, fuel wood, shade, poles for building, food for man, soil fertility enrichment etc. (Okafor, 2002; Mtengeti and Mhelela, 2006).

Indigenous browse species have high persistence in their respective areas (Woodward and Coppock, 1995). They are, however, in danger of extinction due to over use (Mtengeti and Mhelela, 2006). 
Topographic factors such as slope, aspect, altitude and underlying geology, influence the biomass production and quality of forage species (Mutanga et al., 2004). At present, forage species are collected from the wild within the Nsukka rural areas (Onyeonagu and Asiegbu, 2006). There seems a need to focus some research attention on the multipurpose uses of forage species, distribution and utilization of identified forage grass species of rural communities in Nsukka Local Government Area of Enugu State to aid inventorisation. Available information on browse plants of southeastern Nigeria is scanty (Mecha and Adegbola, 1980) and mostly unpublished (Okigbo, 1980; Orok and Duguma, 1987; Okafor and Fernandez, 1987).

The bulk of the feed available to ruminant animals in the tropics is the grass forage, as this can be sourced cheaply (Bamikole, 2003). Smallholder producers of ruminants particularly sheep and goats in Nigeria rely on unimproved natural pasture as the main feed source, backed up with crop residues after harvest (Bamikole et al., 2004). The supply of grass herbage for livestock during the dry months of the year declines substantially (Onyeonagu and Asiegbu, 2006).

An earlier study (Onyeonagu and Asiegbu, 2006) examined the seasonality and preference rating of identified forage species commonly found in the derived savanna zone of Nigeria. However, there is paucity of information on the multipurpose uses of forage species, ease of availability and distribution of forage grass species commonly found in Nsukka, derived savanna zone of Nigeria. Accordingly, research was undertaken within the area to:

Determine the multipurpose uses of forage species commonly found in
Nsukka

Determine the effect of location on the ash and crude fibre contents of some common browse species found in Nsukka.

Estimate the ease of availability and distribution of identified forage grass species found in Nsukka.

\section{Materials and methods}

Semi structured interview schedule were made in this study. Four communities in Nsukka LGA were randomly selected from the area, with Ehalumona, Edemani, Obukpa and Obimo communities representing the East, West, North and South of Nsukka LGA, respectively. Nsukka is situated in a derived savannah ecological zone on latitude $06^{\circ} 52^{\prime} \mathrm{N}$, longitude $07^{\circ} 24^{\prime} \mathrm{E}$ and at an altitude of 447.26 meters above sea level. Five farmers per community were randomly selected and a total of 20 farmers were interviewed.

The information required in the interview schedule was the multipurpose uses of identified forage grass species in Nsukka rural communities (Table 2). The study was carried out between 2005 and 2006. The availability rating of grass species was based on mean scores to the nearest whole number (Key: $1=$ scarce; $2=$ moderately available; and $3=$ easily available). Samples of all the 38 browse species were collected in 2006 for chemical analysis, but only 27 of these were complete at the time of chemical evaluation. The species were identified with the help of a taxonomist in the Department of Crop Science University of Nigeria, Nsukka. The local names were provided by the local farmers.

\section{Chemical Analysis}

The laboratory experiment was a $2 \times 27$ factorial laid out in a completely randomized design (CRD) and was replicated three times. Treatments comprised two locations and 27 browse 
species. Leaves from mature plants were randomly collected from three villages in the Obukpa and Edemani communities for chemical analyses. These plant samples were dried to constant weight in a forcedair oven at a tempeature of $80^{\circ} \mathrm{C}$, and ground using Thomas Wiley laboratory Mill (Mode 4). Determinations of crude fibre and ash contents were as described by Pearson (1976).

Soil Analysis

Soil samples were collected from the three (3) villages in each of the two communities (Obukpa and Edemani) sampled for chemical analysis. The soil samples were collected at random by augering $120 \mathrm{~cm}$ below the soil surface. Sampling was done at four points in each village and soil samples from these points were bulked together. A representative sample was taken to determine the chemical and physical characteristics of the sites.

\section{Statistical analysis}

All data from chemical analysis of samples were statistically analysed using the procedure outlined by Steel and Torrie (1980) for factorial experiment in a Completely Randomized Design (CRD). Separation of treatment means for statistical significance was done using the standard error of the difference between two means (s.e.d.). The results of the interview were analysed using percentages and arithmetic means as described by Steel and Torrie (1980). percentage of all minerals except Calcium than that from Edemani community which is acidic in reaction (Table 1). Base saturation was also higher in Obukpa soil than Edemani.

Except for Mucuna urens, the rest of the browse plants had several other uses besides being browsed by small ruminant animals (Table 2). The family Fabaceae had the greatest numbers of browse plants in the study

Table 1: Soil Physical and Chemical Properties of the Experiment sites

\begin{tabular}{lll}
\hline Mechanical Properties & Edemani & Obukpa \\
\hline Course Sand (\%) & 36.0 & 61.2 \\
Fine Sand (\%) & 46.0 & 24.5 \\
Clay (\%) & 15.0 & 5.0 \\
Silt (\%) & 3.0 & 9.3 \\
Textural Class (\%) & Sandy & Sandy \\
& loam & \\
Chemical Properties & & \\
pH in water & 4.7 & 6.2 \\
pH in KCl & 4.1 & 6.0 \\
Organic Carbon (\%) & 0.42 & 0.399 \\
Organic Matter (\%) & 0.72 & 0.688 \\
Total nitrogen (\%) & 0.042 & 0.07 \\
Total phosphorus (ppm) & 15.95 & 17.11 \\
Base saturation (\%) & 10.74 & 85.16 \\
ExchangeableCations & & \\
(mg/100g soil) & & \\
Potassium & 0.12 & 2.55 \\
Magnesium & 0.2 & 2.4 \\
Calcium & 2.2 & 1.2 \\
Sodium & 0.40 & 4.41 \\
Hydrogen & 0.8 & 2.0 \\
Aluminium & 0.4 & 0.6 \\
CEC & 27.2 & 12.4 \\
\hline
\end{tabular}

\section{Result}

The soil from Obukpa is slightly acidic in reaction and had higher percentage of all minerals except Calcium than that from Edemani community which is acidic in reaction (Table 1). Base saturation was also higher in Obukpa soil than Edemani.

Except for Mucuna urens, the rest of the browse plants had several other uses besides being browsed by small ruminant animals (Table 2). The family Fabaceae had the greatest numbers of browse plants in the study 
Table 2: Multipurpose uses of identified forage browse plants in four rural communities around NSUKKA

\begin{tabular}{|c|c|c|c|}
\hline $\mathrm{S} / \mathrm{NO}$ & FAMILY AND SPECIES & MULTIPURPOSE USE & CODEFOR USES \\
\hline 1 & $\begin{array}{l}\text { Anarcardiaceae } \\
\text { Spondias mumbin } \\
\text { (ijikara) }\end{array}$ & $\begin{array}{l}\text { Stops stomach problems in human; prevents stomach } \\
\text { problem when given to pregnant goats after lambing; } \\
\text { Fruit taken to improve appetite in humans; Medicinal } \\
\text { against inflammation of the throat; Induces milk } \\
\text { production in lactating goats. }\end{array}$ & $1,3,4$ \\
\hline 2 & $\begin{array}{l}\text { Mangifera indica } \\
\text { (mango) }\end{array}$ & $\begin{array}{l}\text { Fruit edible; leaves used against malarial; fuel wood; } \\
\text { shade. }\end{array}$ & $1,2,3,4,11$ \\
\hline 3 & $\begin{array}{l}\text { Amaranthaceae } \\
\text { Amaranthus spinosus } \\
\text { (Inene-itete) }\end{array}$ & Vegetable & 1,3 \\
\hline 4 & $\begin{array}{l}\text { Arecaceae (Palmae) } \\
\text { Elaeis guineensis } \\
\text { (Igunkwu) }\end{array}$ & $\begin{array}{l}\text { Palm oil from fruits; palm wine frominflorescence and } \\
\text { tender aerial plant of the stem; palm kernel oil used to } \\
\text { make soaps; fronds used for thatching and broom } \\
\text { making; fronds are sometimes used as fuel wood when } \\
\text { dry, in making baskets; fence. }\end{array}$ & $1,2,3,5,6,13$ \\
\hline 5 & $\begin{array}{l}\text { Compositae (Asteraceae) } \\
\text { Aspilia africana } \\
\text { (Aramjila) }\end{array}$ & Leaf stops bleeding, & 1,4 \\
\hline 6 & $\begin{array}{l}\text { Chromolaena odorata } \\
\text { (Kitika) }\end{array}$ & $\begin{array}{l}\text { Medicinal in treating minor wounds and stops bleeding, } \\
\text { soil fertility restoration. }\end{array}$ & $1,4,9$ \\
\hline 7 & $\begin{array}{l}\text { Vernonia amygdalina } \\
\text { (Onugbu) }\end{array}$ & $\begin{array}{l}\text { Leaf as medicine against malaria, cough, Diabetics; } \\
\text { antihelminthic; land demarcation; leaves as vegetable. }\end{array}$ & $1,3,5,9$ \\
\hline 8 & $\begin{array}{l}\text { Bignonaceae } \\
\text { Newbouldia leavis (Ejuruoshishi } \\
\text { or Ogirisi) } \\
\text { Bombacaceae }\end{array}$ & $\begin{array}{l}\text { Boundary demarcation; fencing; staking nectar from } \\
\text { flower as juice. }\end{array}$ & $1,3,5,8$ \\
\hline 9 & $\begin{array}{l}\text { Ceiba pentandra } \\
\text { (Akpu Ogwu) }\end{array}$ & Timber; Fuel wood & $1,2,6$ \\
\hline 10 & $\begin{array}{l}\text { Caesalpinoideae } \\
\text { Dialium guineense (Icheku or } \\
\text { Unuagu) }\end{array}$ & $\begin{array}{l}\text { Fruit edible; fuel wood; leaf against malaria and } \\
\text { stomach problem: }\end{array}$ & $1,2,3,4$ \\
\hline 11 & Berlinia grandriflora (Ububa) & Fuel wood; staking & $1,2,8$ \\
\hline 12 & $\begin{array}{l}\text { Caricaceae } \\
\text { Carica papaya Okwurnbekee or } \\
\text { opopo) }\end{array}$ & Fruit edible; medicinal against malaria & $1,3,4$ \\
\hline 13 & $\begin{array}{l}\text { Chrysobalinaceae } \\
\text { Acioa bateri (Ahaba) }\end{array}$ & $\begin{array}{l}\text { Staking; fuel wood; boundary demarcation; chewing } \\
\text { stick; yam ban }\end{array}$ & $1,2,5,7$ \\
\hline 14 & $\begin{array}{l}\text { Euphorbiaceae } \\
\text { Manihol esculenta (Akpu or } \\
\text { Ogodo) }\end{array}$ & Starch; fufu; garri; cassava chips & $1,3,13$ \\
\hline 15 & $\begin{array}{l}\text { Fabaceae } \\
\text { Pterocarpus santalinioides } \\
\text { (Uturukpa) }\end{array}$ & $\begin{array}{l}\text { Vegetable; fuel wood; medicinal against dysentery and } \\
\text { in clearing the system of newborn babies; land } \\
\text { demarcation. }\end{array}$ & $1,2,3,4,5$ \\
\hline 16 & $\begin{array}{l}\text { Baphia nitida } \\
\text { (Aboshi) }\end{array}$ & $\begin{array}{l}\text { Fuel wood; medicinal against skin rashes and malaria; } \\
\text { chewing stick; treatment of wounds; boundary } \\
\text { demarcation. }\end{array}$ & $1,2,4,5,7$ \\
\hline 17 & Cajanus cajan (Agbugbu) & Seed edible; fuel wood; staking & $1,2,3,8$ \\
\hline 18 & Mucuna urens (Egbara)) & & 1 \\
\hline
\end{tabular}




\section{Table 2 continued}

\begin{tabular}{|c|c|c|c|}
\hline 19 & $\begin{array}{l}\text { Calapogonium mucunoids } \\
\text { (Ogbanala) }\end{array}$ & Soil fertility restoration & 1,9 \\
\hline 20 & $\begin{array}{l}\text { Icancinaceae } \\
\text { Icacina trichantha } \\
\text { (Urumbia) }\end{array}$ & Medicinal against scabies & 1,4 \\
\hline 21 & $\begin{array}{l}\text { Irvingia gabonensis } \\
\text { (Ujuru) }\end{array}$ & Fruit edible; fuel wood; soup thickener & $1,2,3$ \\
\hline 22 & $\begin{array}{l}\text { Lauraceae } \\
\text { Persea americana } \\
\text { (Ube bekee). } \\
\text { Lecythidaceae }\end{array}$ & $\begin{array}{l}\text { Fruit edible; leaf medicinal against malaria; shade; } \\
\text { reduces high blood pressure. }\end{array}$ & $1,3,4,11$ \\
\hline 23 & $\begin{array}{l}\text { Napoleona imperialis (Odure or } \\
\text { ukpodu) } \\
\text { Malvaccae }\end{array}$ & $\begin{array}{l}\text { Green manure; medicinal against stomach problem and } \\
\text { dysentery. }\end{array}$ & $1,4,9$ \\
\hline 24 & $\begin{array}{l}\text { Sida acuta } \\
\text { (Ogbogu) } \\
\text { Meliaceae }\end{array}$ & Erosion control & 1,10 \\
\hline 25 & Azadirachta indica (Dogonyaro). & Leaf as medicine against malaria; fuel wood. & $1,2,4$ \\
\hline 26 & $\begin{array}{l}\text { Mimosaceae } \\
\text { Pentachlethra macrophylla } \\
\text { (Akpaka) }\end{array}$ & $\begin{array}{l}\text { Fruit edible; fuel wood; medicinal against malaria; } \\
\text { making knife handle; mortar and pestle. }\end{array}$ & $1,2,3,4,12$ \\
\hline 27 & $\begin{array}{l}\text { Moraceae } \\
\text { Ficus thonningii }(\mathrm{Ogbu})\end{array}$ & Tender leaves as vegetables yam ban; as fence; & $1,3,5$ \\
\hline 28 & Treculia africana (Ukwa) & Fruit edible, fuel wood & $1,2,3$ \\
\hline 29 & Milicia excelsa (Iroko) & Timber; fuel wood & $1,2,6$ \\
\hline 30 & $\begin{array}{l}\text { Musaceae } \\
\text { Musa sapientum (Unene) }\end{array}$ & $\begin{array}{l}\text { Fruit edible; leaf for wrapping; stem for preserving } \\
\text { Cocoyamin storage; part of stem used as rope. }\end{array}$ & 1,3 \\
\hline 31 & $\begin{array}{l}\text { Myrtaceae } \\
\text { Psidium guajava (Gova) }\end{array}$ & $\begin{array}{l}\text { Fruit edible; fuel wood; staking; medicinal against } \\
\text { malaria; shade. }\end{array}$ & $1,2,3,4,8,11$ \\
\hline 32 & $\begin{array}{l}\text { Rubiaceae } \\
\text { Nauclea diderrichii (Uvuru) }\end{array}$ & Timber; fuel wood. & $1,2,6$ \\
\hline 33 & $\begin{array}{l}\text { Sterculiaceae } \\
\text { Cola acuminata (Oji Igbo) }\end{array}$ & Fruit edible; fuel wood; shade & $1,2,3,11$ \\
\hline 34 & Cola gigantica (Oji enyi) & Stake; fuel wood & $1,2,8$ \\
\hline 35 & Triplochiton scleroxylon (Okpo). & Timber; fuel wood & $1,2,6$ \\
\hline 36 & $\begin{array}{l}\text { Tiliaceae } \\
\text { Glyphaea brevis (Utarioba or ubeh } \\
\text { or Anyachu) }\end{array}$ & $\begin{array}{l}\text { Fuel wood; yamban; boundary demarcation; seed as } \\
\text { medicine against cough and dysentery; }\end{array}$ & $1,2,4,5$ \\
\hline 37 & $\begin{array}{l}\text { Verbenaceae } \\
\text { Gmelina arborea(Melina) }\end{array}$ & $\begin{array}{l}\text { Fuel wood; leaf as medicine against malaria when in } \\
\text { mixture with Dogonyaro; timber, shade }\end{array}$ & $1,2,4,6$ \\
\hline 38 & Vitex doniana (Uchakiri). & Timber; vegetable; fuel wood; & $1,2,3,6$ \\
\hline
\end{tabular}




\begin{tabular}{lll} 
KEY: & & \\
CODE & & \\
FOR & & NUMBER \\
USES & & OF SPECIES \\
1 & & \\
2 & Edible to live stock & All \\
3 & Provide fuel wood & 22 \\
& Edible fruits \& leaves as & 20 \\
& vegetable (food for man) & \\
4 & Human \& Veterinary & 16 \\
& medicine & \\
5 & Boundary demarcation and & 8 \\
& fence & \\
6 & Provide building poles / & 7 \\
& roofing materials (Timber) & \\
7 & Chewing stick & 2 \\
8 & Staking material & 5 \\
9 & For soil fertility enrichment & 4 \\
10 & Soil erosion control & 1 \\
11 & Provides shade & 4 \\
12 & Making tool handles & 1 \\
13 & Raw materials for some & 2 \\
& industries & \\
\cline { 2 - 3 } &
\end{tabular}

areas followed by the families Compositae (Asteraceae) and Moraceae with 3 species each. Icancina trichantha produced significantly $(\mathrm{P}<0.05)$ the highest crude fibre content compared with the other browse species (Table 3). Species from Edemani community had higher crude fibre contents of browse plants than those from Obukpa community. Gmelina arborea collected from Obukpa had the least crude fibre content. Elaeis giuneensis produced significantly $(\mathrm{P}<0.05)$ the highest ash content while Berlinia grandriflora had the least ash content among the sampled species (Table 3). Species collected from Edemani community had higher ash content of browse species than those from Obukpa community. Elaeis guineensis from Edemani area had significantly $(\mathrm{P}<$ 0.05 ) the highest ash content while Cola gigantica collected from Obukpa had the least content.

Besides being used in livestock feeding (Table 4), most of the forage grass species are used for other purposes.
Six (6) grass forage species were identified in the 4 communities (Table 5). The most frequently used grass species (with mean usage $=15 \%$ ) across all sampled communities include: Andropogon gayanus and Anthephora ampulaceae. Panicum maximum was also found to be frequently used while Setaria barbata had a moderate usage in small ruminant nutrition in the communities. Loudetia orundinaceae and Hyparrhenia rufa are poorly used in small ruminant nutrition in the area.

All the grass species identified are moderately available in the area of study (Table 6). The species Panicum maximum and Setaria barbata are not common in Obimo community. Setaria barbata is not common in Edemani area while Loudetia orundinaceae and Hyparrhenia rufa found usage only in Obukpa community.

\section{Discussion}

Besides browsing, greater number of the browse species (22 species) were used for fuel wood and this compares favourably with the results of Mtengeti and Mhelela (2006) who

reported that greater number of browse species (20 species) were used for fuel wood in central semi arid part of Tanzania. The use of Aspilia africana and Vernonia amygdalina as medicinal plants for human is in agreement with what has been reported in Southeastern Nigeria (Okafor, 2002). bringing about the disappearance of some plant species (Mtengeti and Mhelela, 2006). Therefore, a fast screening method to identify the potential indigenous browse plant species for domestication should be developed. The families Fabaceae, Compositae (Asteraceae) and Moraceae have great number of species used as browse plants. 
Table 3: Effects of location on crude fibre and ash contents $(\%)$ of browse species.

\begin{tabular}{|c|c|c|c|c|c|c|}
\hline & \multicolumn{3}{|c|}{ Crude Fibre (\%) } & \multicolumn{3}{|c|}{ Total Ash (\%) } \\
\hline Species & Edemani & Obukpa & Mean & Edemani & $\begin{array}{c}\text { Obukp } \\
\mathrm{a}\end{array}$ & Mean \\
\hline Baphia nitida & 58.33 & 23.83 & 41.08 & 7.67 & 3.00 & 5.33 \\
\hline $\begin{array}{l}\text { Pentachlethra } \\
\text { macrophylla }\end{array}$ & 50.00 & 45.33 & 47.67 & 6.00 & 7.33 & 6.67 \\
\hline Manihot esculenta & 30.33 & 27.67 & 29.00 & 16.67 & 14.33 & 15.50 \\
\hline Newbouldia leavis & 67.50 & 53.67 & 60.58 & 11.00 & 9.67 & 10.33 \\
\hline Gmelina arborea & 41.67 & 11.67 & 26.67 & 8.67 & 7.67 & 8.33 \\
\hline Psidium guajava & 64.17 & 29.17 & 46.67 & 8.33 & 4.33 & 6.33 \\
\hline Dialium guineense & 48.83 & 29.67 & 39.25 & 8.67 & 3.33 & 6.00 \\
\hline Elaeis guineensis & 41.00 & 45.00 & 43.00 & 37.33 & 9.67 & 23.50 \\
\hline Milicia excelsa & 32.17 & 27.17 & 29.67 & 14.67 & 6.33 & 10.50 \\
\hline Ficus thonningii & 47.17 & 33.33 & 40.25 & 22.67 & 17.33 & 20.00 \\
\hline Cola gigantica & 60.17 & 14.50 & 37.33 & 8.00 & 2.00 & 5.00 \\
\hline Cola acuminata & 49.17 & 41.83 & 45.50 & 7.67 & 7.00 & 7.33 \\
\hline Carica papaya & 26.00 & 21.83 & 23.92 & 20.00 & 26.67 & 23.33 \\
\hline Bambusa vulgaris & 54.67 & 41.33 & 48.00 & 13.00 & 11.67 & 12.33 \\
\hline Persea americana & 43.67 & 47.00 & 45.33 & 8.33 & 7.00 & 7.67 \\
\hline Berlinia & 55.17 & 14.67 & 34.92 & 5.33 & 2.67 & 4.00 \\
\hline $\begin{array}{l}\text { grandriflora } \\
\text { Irvingia } \\
\text { gabonensis }\end{array}$ & 52.00 & 34.50 & 43.92 & 9.33 & 9.33 & 9.33 \\
\hline Treculia africana & 39.00 & 48.83 & 43.92 & 11.67 & 7.67 & 9.67 \\
\hline Musa sapientum & 57.33 & 28.50 & 42.92 & 12.33 & 4.33 & 8.33 \\
\hline
\end{tabular}

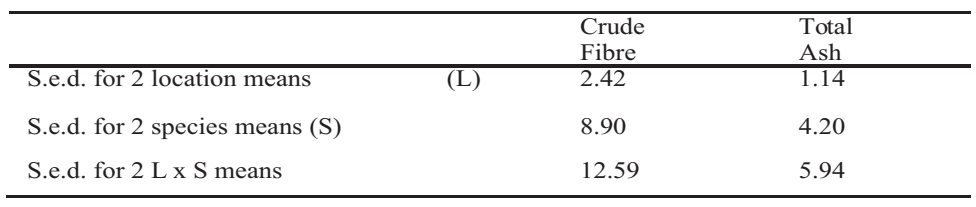

Table 4: Multipurpose uses of identified forage grass plants in Nsukka rural areas.

\begin{tabular}{cllc}
\hline NO & SPECIES & MULTIPURPOSE USES & $\begin{array}{c}\text { CODE FOR } \\
\text { USES }\end{array}$ \\
\hline 1 & $\begin{array}{l}\text { Andropogon gayamus } \\
\text { (Owa) }^{1}\end{array}$ & $\begin{array}{l}\text { Soil fertility restoration (green } \\
\text { manure); for lighting }\end{array}$ & $1,2,3$ \\
2 & $\begin{array}{l}\text { Anthephora } \\
\text { ampulaceae } \\
\text { (Ejo) }\end{array}$ & Soil fertility restoration (manure) & 1,2 \\
3 & $\begin{array}{l}\text { Panicum maximum } \\
\text { (Icharaku) }\end{array}$ & Green manure; soil erosion control & $1,2,5$ \\
4 & $\begin{array}{l}\text { Setaria barbata } \\
\text { (Ebandu) }\end{array}$ & Soil fertility restoration (manure) \\
5 & $\begin{array}{l}\text { Loudetia orundinaceae } \\
\text { (Ize) }\end{array}$ & For lighting; roofing material & 1,2 \\
6 & $\begin{array}{l}\text { Hyparrhenia rufa } \\
\text { (Ikpo) }\end{array}$ & Roofing material & $1,3,4$ \\
\hline
\end{tabular}




\begin{tabular}{|c|c|c|c|c|c|c|}
\hline S/No & Species & Obukpa & Obimo & $\begin{array}{l}\text { Eha- } \\
\text { Alumona } \\
\end{array}$ & Edemani & Mean \\
\hline 1 & $\begin{array}{l}\text { Andropogon gayanus } \\
\text { (Owa) } \mathrm{i}\end{array}$ & 25.0 & 25.0 & 20.0 & 25.0 & 23.27 \\
\hline 2 & $\begin{array}{l}\text { Anthephora a mpulaceae } \\
\text { (Ejo) }\end{array}$ & 15.0 & 25.0 & 10.0 & 20.0 & 17.50 \\
\hline 3 & $\begin{array}{l}\text { Panicum maximum } \\
\text { (Icharaku) }\end{array}$ & 25.0 & - & 15.0 & 15.0 & 13.75 \\
\hline 4 & $\begin{array}{l}\text { Setaria barbata } \\
\text { (Ebandu) }\end{array}$ & 20.0 & - & 5.0 & - & 6.25 \\
\hline 5 & $\begin{array}{l}\text { Loudetia orundina ceae } \\
\text { (Ize) }\end{array}$ & 5.0 & - & - & - & 1.25 \\
\hline 6 & $\begin{array}{l}\text { Hyparrhenia rufa } \\
\text { (Ikpo) }\end{array}$ & 5.0 & - & - & - & 1.25 \\
\hline
\end{tabular}

Table 6: Availability and distribution of forage grass plants in the sampled communities (Availability rating is based on mean scores to the nearest whole numbers: figures also indicate distribution areas). Key: $1=$ scarce; 2 = moderately available; $3=$ easily available

\begin{tabular}{|c|c|c|c|c|c|c|}
\hline S/No. & Species & Obukpa & Obimo & $\begin{array}{l}\text { Eha- } \\
\text { Alumona }\end{array}$ & Edemani & Mean \\
\hline 1 & $\begin{array}{c}\text { Andropogon gayanus } \\
\text { (Owa) })^{1}\end{array}$ & 2 & 2 & 2 & 3 & 2 \\
\hline 2 & $\begin{array}{c}\text { Anthephora ampulaceae } \\
\text { (Ejo) }\end{array}$ & 2 & 2 & 2 & 2 & 2 \\
\hline 3 & $\begin{array}{c}\text { Panicum maximum } \\
\text { (Icharaku) }\end{array}$ & 2 & - & 3 & 2 & 2 \\
\hline 4 & $\begin{array}{l}\text { Setaria barbata } \\
\text { (Ebandu) }\end{array}$ & 3 & - & 3 & - & 2 \\
\hline 5 & $\begin{array}{c}\text { Loudetia orundinaceae } \\
\text { (Ize) }\end{array}$ & 2 & - & - & - & 1 \\
\hline 6 & $\begin{array}{c}\text { Hyparrhenia rufa } \\
\text { (Ikpo) }\end{array}$ & 2 & - & - & - & 1 \\
\hline
\end{tabular}

Species in these plant families have been shown to have very large number of palatable and very palatable species (Onyeonagu and Asiegbu, 2006). The slightly acidic nature of the soil from Obukpa community (with higher nitrogen content) compared with the acidic soil from Edemani community (with lower nitrogen content) could be a reason for the lower crude fiber contents of the browse species from Obukpa compared to those from Edemani. Nitrogen application has been shown to reduce pasture crude fiber and ash-contents (Gilmour et al., 1979). Differences in species tolerance to soil conditions and extent of land use for farming activities in the study areas could account for the differences in quality of the species.

The moderate availability of the grass species could be explained by the fact that these species are available only during the months of March to November each year in the study area (Onyeonagu and 
Asiegbu, 2006). The presence of most of the identified forage grass species in the derived Savannah Zone of Nigeria was earlier reported by Onifade and Agishi (1988). Most of the identified forage species have been shown to be very palatable to ruminant livestock (Onyeonagu and Asiegbu, 2006). Therefore, a fast screening method to identify the potential indigenous forage grass and browse species for domestication should be developed.

\section{References}

Bamikole, M.A., Ikhatua, U.J., Arigbede, O.M., Babayemi, O.J. and Etela, I. 2004. An evaluation of the acceptability as forage of some nutritive and antinutritive components and of the dry matter degradation profiles of five species of Ficus. Tropical Animal Health and Production, 36: 157167.

Gilmour, A.R., Thompson, R., Cullis, B.R. and Welham, S.J. 1979. Grazing management ASREML. NSW Agriculture 16-26.

Mecha, I. and Adegbola, T.A. 1980. Chemical composition of some Southern Nigeria forage eaten by goats. In: Le Houerou, H. N. (Ed). Browse in Africa; the current state of knowledge, International Livestock Centre for Africa, Addis Ababa.

Mtengeti, E.J. and Mhelela, A. 2006. Screening of potential indigenous browse species in semi-arid central Tanzania. A case of Gairo division. Livestock Research for Rural Development 18 (8) 14.

Mutanga, O., Prins, H.T., Skidmore, A.K., Van. Wieren, S., Huizing, H., Grant, R., Peel, M. and Biggs, H. 2004. Explaining grass-nutrient patterns in a savannah range land of southern Africa. Journal of Biogeography 31:819 829.

Okafor, J.C. 2002. Tropical plants in health care delivery in Nigeria: contributions of some members of compositae (Asteraceae) Journal of College of Medicine, 7 (2): 129131.

Okafor, J.C. and Fernandez ECM 1987. Compound farms of Southeastern Nigeria: A predominant agroforestry home garden system with crops and small livestock. Agrogorestry Systems, 5: 153165.

Okigbo, B.N. 1980. Plants and Foods in Igbo culture Ahiajoku lecture 28 November, 1980. Imo State Government Press, Owerri.

Onyeonagu, C.C. and Asiegbu, J.E. 2006. Frequency of Collection, Distance from source of collection, Seasonality and preference rating of identified forage species in Nsukka Rural Communities of Enugu State Nigeria. Agro-Science Journal of Tropical Agriculture, food Environment and Extension 5 (2) 33 39.

Orok, E.J. and Duguma, B. 1987. Browse use and small ruminant production in Southeastern Nigeria. In: Reynolds, L., Atta-Krah, A. N. (Eds). Proceedings of Symposium. International Livestock Centre for Africa (ILCA). Humid Zone Programme, Ibadan, pp: 212.

Pearson, D. 1976. The chemical analysis of food. Churchill livingstone, Edinburgh London and New York. Pp 525.

Steel, G.D. and Torrie, J.H. 1980. Principles and procedures of statistics: A Biometrical Approach, $2^{\text {nd }}$ Ed. McGraw Hill Book Company. Inc. New York 633, pptxx1.

Woodward, A. and Coppock, D.L. 1995. Role of plant defensive mechanism in the utilization of native browse plants in Southern Ethiopia. Agroforestry Systems 32: 147-161. 